๑ Entomologica Fennica. 13 November 2000

\title{
Comparative descriptions of the immature stages and ecology of five Finnish melitaeine butterfly species (Lepidoptera: Nymphalídae)
}

\author{
Niklas Wahlberg
}

\begin{abstract}
Wahlberg, N. 2000: Comparative descriptions of the immature stages and ecology of five Finnish melitaeine butterfly species (Lepidoptera: Nymphalidae). Entomol. Fennica 11:167-174.
\end{abstract}

The immature stages of five Finnish melitaeine butterfly species are described, together with a short discussion of the ecology of each species. The five species are Melitaea cinxia (L.), M. diamina (Lang), M. athalia (Rottemburg), Euphydryas maturna (L.) and E. aurinia (Rottemburg). The eggs of the Euphydryas species are distinguished from the eggs of the Melitaea species by their bright yellow colouration when freshly laid which changes to brown after some days. Eggs of the Melitaea species are creamy yellow until hatching. Prediapause larvae are also distinct between these two groups, with Euphydryas species having fine spotting on the body and a very long terminal seta on the spines. These features are absent in the Melitaea species. All larvae diapause as mid-instar larvae, usually in the fourth instar. Behaviour of postdiapause larvae varies between species from highly gregarious ( $M$. cinxia and $E$. aurinia) through gregarious until diapause ( $M$. diamina and E. maturna) to solitary (M. athalia).

Niklas Wahlberg, Metapopulation Research Group, Department of Ecology and Systematics, Division of Population Biology, P.O. Box 17 (Arkadiankatu 7), FIN00014 University of Helsinki, Finland; e-mail: niklas.wahlberg@helsinki.fi

Received 12 October 1999, accepted 13 March 2000

\section{Introduction}

The tribe Melitaeini is a group of butterflies with about 250 species worldwide, which are placed into four groups of species (Higgins 1981, Wahlberg \& Zimmermann, in press). Of the four groups, two are found in Europe; species belonging to the genus Euphydryas Scudder (split into Hypodryas and Eurodryas by Higgins 1978) form one group, and species belonging to Melitaea Fabricius (including Mellicta Billberg) the other. Two additional groups are found only in North and South America and comprise the genera Phyciodes Hübner and Chlosyne Butler (Higgins
1981, Wahlberg \& Zimmermann, in press). The generic classification of the species under study follows Karsholt and Razowski (1996).

Butterflies belonging to the tribe Melitaeini have been studied intensively since the 1960 's, especially in North America (e.g. Ehrlich et al. 1975). These studies have mainly been ecological with an emphasis on population dynamics (Hanski \& Kuussaari 1995) and the interaction between larvae and their host plants (Bowers 1983). Even though the life histories of many studied species are well known, the identification of the immature stages is often not possible for those not explicitly studying melitaeine species. 
Melitaeine Iarvae are often conspicuous in nature, as just about all species are gregarious at some larval stage. Many species spin a web in the early instars, within which they may feed, excrete and shed their skin. Most species in the genera Melitaea and Euphydryas go through six instars before pupation. All species diapause as mid-instar larvae, usually in the fourth instar, though some species may develop directly without diapause in the southern parts of their range.

Over the past few years I have reared five species (Melitaea cinxia (L.), M. diamina (Lang), $M$. athalia (Rottemburg), Euphydryas maturna (L.) and E. aurinia (Rottemburg)) through their entire life cycle. In this paper I describe the immature stages of these species and briefly discuss the ecology of each species. More detailed descriptions of the life histories of these species have been published earlier (Kuussaari et al. 1995, Wahlberg 1995, 1997a, 1997b, 1998, 1999, Klemetti \& Wahlberg 1997, Komonen 1997, Selonen 1997).

\section{Material and methods}

I reared larvae under laboratory conditions on their preferred host plant (which were either potted or leaves were gathered fresh from the field). For three species I was able to measure the egg height and width using a measuring ocular on a dissecting microscope, otherwise measurements were made using a standard ruler. Larvae of $M$. cinxia originated from the Alland (Ahvenanmaa) Islands, SW Finland; those of $M$. diamina from Orivesi, S central Finland; $M$. athalia, E. matur$n a$ and E. aurinia larvae from Joutseno, SE Finland. All de- scriptions are of live larvae that were not prepared in any way. I have used the terminology of Scott (1986) to describe the immature stages.

\section{Results}

\subsection{General results}

The larvae of melitaeine species have 13 segments consisting of 3 thoracical segments, each with a pair of true legs, and 10 abdominal segments. Abdominal segments 3-6 and 10 have a pair of prolegs each. The first six abdominal segments have 11 branching spines (scoli), which I have numbered from 1 to 6 starting from the top (Fig. 1).

\subsection{Melitaea cinxia}

Egg. Nearly spherical with flattened top and base; approximately 18 longitudinal ridges extending from top to base; sides and top with irregular pitting; colour yellow-green when oviposited, changing to creamy yellow on second day.

First instar. Head black with colourless setae; body yellowish brown (not transparent) with pale brown setae arising from brown papillae and gut giving dark green colour to fore body. True legs almost black, prolegs concolourous to body. First thoracic segment with dark prothoracic shield.

Second instar. Head black with colourless setae; body dark chocolate brown with obscure

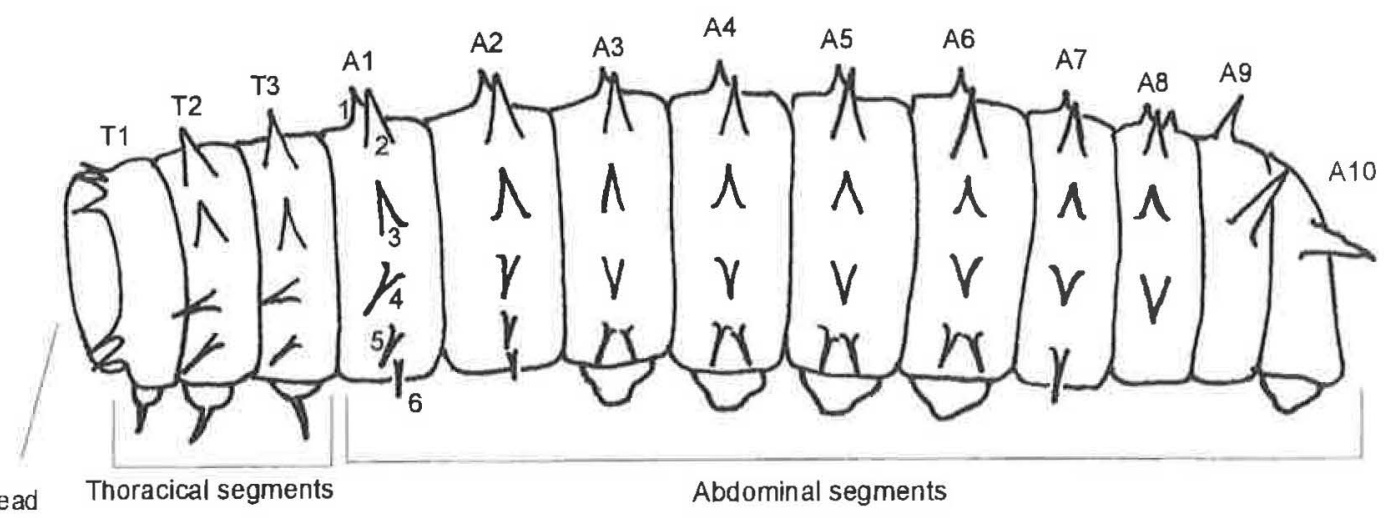

Head

Thoracical segments

Abdominal segments

Fig. 1.The general body plan of a melitaeine larva. 
greenish spots and with lateral grey-green band; branching spines develop from papillae and simple setae of first instar; spine shafts light grey with colourless setae; terminal setae slightly longer than other setae on dorsal spines; base of shaft with light grey circle. True legs blackish, prolegs grey.

Third instar. Head capsule black with colourless setae. Body almost black with faint grey spots. Spine shafts yellowish grey with colourless setae; terminal setae as long or slightly longer than other setae on dorsal spines. True legs black, prolegs yellowish brown.

Feeding fourth instar. This instar is not always present. Head capsule black or black with reddish tinge. Body black with grey spots. Spine shafts pale brown with brown setae. True legs black, prolegs pale orange.

Diapausing fourth or fifth instar. Head capsule orange-red with some black markings. Body black with grey spots. Spine shafts jet black with black setae. True legs black, prolegs reddish orange.

Postdiapause fifth or sixth instar. Continued development of previous patterns. Head capsule and prolegs dark red. Larva about $15 \mathrm{~mm}$ in length.

Postdiapause sixth or seventh instar. Colours and patterns as in previous instar. Larva about 20 mm long.

Pupa. Ground colour brown with black markings. Abdominal segments have 3-5 bright orange cones on dorsal side.

Ecology. The ecology of $M$. cinxia in Finland is well known (Hanski et al. 1994, 1995, Kuussaari et al. 1995, Wahlberg 1995). The butterfly is oligophagous in the Åland (Ahvenanmaa) Islands. Females lay their eggs in batches with an average size of 170 eggs (Wahlberg 1995) on only two host plants: Plantago lanceolata (Plantaginaceae) and Veronica spicata (Scrophulariaceae) (Kuussaari et al. 1995). The eggs are laid in a multilayered pile. Eggs hatch in the middle of July and larvae live in groups, spinning conspicuous webs that often cover the host plant completely.

Larvae diapause within a winter web in either fourth or fifth instar. The feeding fourth instar larva described above does not always occur. Third instar larvae shed their skin to become either feeding fourth instar or diapausing fourth instar larvae, which differ in colour and pattern from each other. Diapausing fourth and fifth instar larvae are indistinguishable from each other. The significance of this extra larval instar has not been studied yet, but it could conceivably affect the size of the adult butterflies.

Postdiapause larvae remain together in groups until ultimate instar. Larvae bask together in sunny weather during spring and are able to raise their temperature well above ambient (Kuussaari 1998). Basking promotes increased growth rates of the larvae in a group. Larvae are sometimes able to escape parasitism by the braconid parasitoid $\mathrm{Co}$ tesia melitaearum (Wilkinson), which are unable to take advantage of solar warmth and thus develop slower than their hosts (Lei et al. 1997). Larvae pupate singly within dense vegetation.

Adult males generally use the perching tactic when searching for females to mate with (Wahlberg 1995). Perching males set up territories near stands of the host plant, where females are likely to eclose. Some males are not able to defend territories and patrol over larger areas (Wahlberg 1995). Females usually mate only once (Kuussaari 1998), though males do not place a mating plug over the opening of the bursa copulatrix (Wahlberg 1995).

\subsection{Melitaea diamina (after Wahlberg 1997a)}

Egg. Nearly spherical with flattened top and base; approximately 22 longitudinal ridges $(21-23)$ extending from top to base; sides and top with irregular pitting; colour yellow-green when oviposited, changing to creamy yellow on second day.

First instar. Head dark brown with some colourless setae. Body transparent yellow with colourless setae arising from papillae darker than body and gut giving green colour to fore body; first thoracic segment with prothoracic shield. Prolegs concolorous with body, true legs are browner. Larva about $2 \mathrm{~mm}$ in length.

Second instar. Head black with pale brown setae. Body developing characteristic colour pattern of later instars: brown with pale grey spiracles; ventrolateral band dull grey; prothoracic shield on first thoracic segment with black setae; branching spines develop from papillae and simple setae of first instar; shafts of spines pale grey with black setae. Prolegs pale grey, true legs dark brown. Larva about $4 \mathrm{~mm}$ long. 
Third instar. Head capsule black with black setae. Body dark brown with grey spiracles; ventrolateral band no longer distinct, but lighter brown in colour than rest of body. Prolegs grey and true legs dark brown. Spine shafts almost black with grey tips and black setae; base of spine shaft with grey ring around. Larva about $6 \mathrm{~mm}$ in length

Fourth instar. Head capsule black with black setae. Body dark brown with grey dots and dark stripe on upperside; light brown on underside. True legs dark brown. Prolegs white with light brown bases. Spines black with yellow ring around base of shaft; fringing spine shafts dark yellow; dorsal spine shafts black with grey tips. Larva about $7 \mathrm{~mm}$ long.

Fifth instar. Overall pattern as in previous instar, but body black and all spine shafts dark yellow with grey tips. Dots on body clearer and lighter grey in colour. Larva about $11 \mathrm{~mm}$ in length.

Sixth instar. Continued development of previous patterns. Dorsal spine shafts bright yellow with grey tips, fringing spine shafts entirely grey; bases of spine shafts black along with rest of body. Larva about $18 \mathrm{~mm}$ long.

Pupa. Ground colour ivory white with black markings. Abdominal segments have 3-5 bright orange cones on dorsal side. Pupa about $11 \mathrm{~mm}$ in length.

Ecology. The life history of $M$. diamina is described in detail in Wahlberg (1997a). In Finland the species is monophagous on Valeriana sambucifolia (Valerianaceae). Females oviposit their eggs in batches with an average size of 100 eggs, usually in one layer. Prediapause larvae live in groups, spinning thin webs underneath the leaves of the host plant.

Larvae diapause in the fourth instar in small groups inside dead, curled leaves close to their host plant. Fourth instar postdiapause larvae can be found basking in small groups of 2-16 individuals, but later instars usually feed singly (Wahlberg 1997a).

The male butterflies exclusively use the patrolling tactic when searching for females to mate with (Wahlberg 1997a). The males place a mating plug over the females' bursa copulatrix and the females probably mate only once.

\subsection{Melitaea athalia}

Egg. Nearly spherical with flattened top and base; approximately 22 longitudinal ridges extending from top to about half-way down sides; top with irregular pitting; colour yellow-green when oviposited, changing to creamy yellow on second day. Width $0.64 \mathrm{~mm}(\mathrm{n}=10)$, height $0.67 \mathrm{~mm}(\mathrm{n}=$ $10)$.

First instar. Head almost black with few colourless setae. Body transparent brownish yellow with pale brown setae arising from brown papillae (10 per segment) and gut giving light green colour to fore body. True legs and prolegs concolorous with body. First thoracic segment with prothoracic shield. Larva about $2.5 \mathrm{~mm}$ in length.

Second instar. Head black with light brown setae. Body brownish yellow with gut still colouring fore body green. Body with middorsal and two dorsolateral brown bands. Prolegs concolorous with body, true legs blackish. Branching spines develop from papillae and simple setae of first instar; shafts of spines grey with black setae; base of shafts with cream yellow ring; location of spines on first six abdominal segments: one in middorsal band, one between bands, one in dorsolateral band and three below dorsolateral band. Larva about $4 \mathrm{~mm}$ long.

Third instar. Head capsule black with black setae. Body dark grey with grey spots. Prolegs grey and true legs black. Spine shafts with black setae and grey tips. Middorsal spine shafts black, dorsolateral spine shafts blackish yellow, lateral spine shafts black, two ventral spine rows with dark grey shafts. Larva about $5 \mathrm{~mm}$ in length.

Fourth instar. Head capsule black with black setae. Body black with grey spots. True legs blackish brown, prolegs grey. Shafts of middorsal, lateral and ventrolateral spine rows blackish brown; shafts of two dorsolateral spine rows adjacent to middorsal spine row orange with dark tip; base of latter spine shafts concolourous with body; base of other spine shafts yellowish grey. Larva about $10 \mathrm{~mm}$ long.

Fifth instar. Continued development of patterns and colours of previous instar. Base of ventrolateral and middorsal spines concolourous with body; ventrolateral spine shafts black, middorsal spine shafts yellowish black; dorsolateral spine shafts orange with orange base, though relative 
area smaller than in 4th instar; all spine shafts with grey tips. True legs black, prolegs dark grey. Larva about $12 \mathrm{~mm}$ in length.

Sixth instar. Overall pattern as in previous instar, but ventrolateral spine shafts no longer black; middorsal spine shafts same orange as dorsolateral spine shafts; adjacent lateral spine shafts lighter orange; ventrolateral spine shafts grey. Base of setae on head capsule grey, giving head a spotted appearance. Larva about $20 \mathrm{~mm}$ long.

Pupa. Ground colour dirty brownish white with black markings. Abdominal segments have 5 orange cones on dorsal side. Two orange cones on back of thorax. Pupa about $11 \mathrm{~mm}$ in length.

Ecology. The life history of $M$. athalia in Finland is described in detail in Wahlberg (1997b) and Selonen (1997). The species is oligophagous in Finland, with prediapause larvae having been recorded definitely on Veronica chamaedrys, $V$. spicata and Plantago lanceolata. Postdiapause larvae also feed on Melampyrum pratense (Scrophulariaceae), but this has not been confirmed for prediapause larvae in the field. Females oviposit their eggs in batches of on average 53 eggs, in an untidy pile. Females may lay their eggs on a plant adjacent to the host plant. The larvae do not feed on that plant but move to the host plant soon after hatching. In the first instar, the larvae spin a very thin web beneath the leaves. Melitaea athalia larvae disperse already in the second instar and are solitary until diapause.

The larvae diapause singly in the fourth instar in the leaf litter around their host plant. The postdiapause larvae feed and bask singly on dead leaves or other dark substrates (Wahlberg 1997b).

The males use only patrolling tactic when searching for females to mate with (Wahlberg 1997b). The males place a mating plug over the females' bursa copulatrix and the females usually mate only once.

\subsection{Euphydryas maturna}

Egg. Nearly pyramidal with flattened top and base; bright yellow when oviposited, changing to brown after 3 days; approximately 19 distinct longitudinal ridges extending most of the distance from apex to base. Width $0.67 \mathrm{~mm}(n=11)$, height 0.65 $\mathrm{mm}(n=10)$.
First instar. Head black with colourless setae. Body dark yellowish brown with gut giving green colour to fore body. Body with very fine spotting (not distinct). Body with colourless setae arising from dark brown papillae. True legs dark brown and prolegs concolorous with body. First thoracic segment with prothoracic shield, last abdominal segment with dark suranal plate. Larva about $3.2 \mathrm{~mm}$ in length.

Second instar. Head black with black setae. Body dark yellowish brown with gut still colouring fore body green; body with middorsal and ventrolateral bands. Branching spines develop from papillae and simple setae of first instar. Spine shafts and setae black; terminal seta about three times longer than other setae. True legs black, prolegs dark grey. Larva about $5 \mathrm{~mm}$ long.

Third instar. Head capsule black with black setae. Body dark brown with yellowish green middorsal band and ventrolateral bands. Prolegs and underside yellow, true legs black. Shafts of middorsal and two dorsolateral spine rows black, shafts of two ventrolateral spine rows yellowish black. Setae black, terminal setae 2 times longer than other setae. Larva about $9 \mathrm{~mm}$ in length.

Fourth instar. Continued development of patterns and colours of previous instar. Body, spines, setae, head capsule and true legs black; middorsal and lateral bands made up of lemon yellow large spots with black spiracles. Prolegs light brown, underside greenish grey. Larva about 13 $\mathrm{mm}$ long.

Fifth instar. Overall pattern as in previous instar, but prolegs pinkish with brown on the outside. Larva about $16 \mathrm{~mm}$ in length.

Sixth instar. Overall pattern as in previous instars, but underside pale yellow and head capsule noticably larger in relation to body size than in 5th instar. Larva about $28 \mathrm{~mm}$ long.

Pupa. Ground colour ivory white with black markings. Abdominal segments with 5 orange cones on dorsal side. 2 orange cones on back of thorax. Pupa about $14 \mathrm{~mm}$ in length.

Ecology. The life history of E. maturna has been described in detail in Selonen (1997) and Wahlberg $(1998,1999)$. The species is oligophagous in Finland, feeding on Melampyrum pratense and Veronica longifolia (Scrophulariaceae) There are also records of a prediapause group on Viburnum opulus (Caprifoliaceae) and postdia- 
pause larvae on Lonicera xylosteum (Caprifoliaceae). Wahlberg $(1998,1999)$ has shown that in Finland the most important host plant of E. maturna is $M$. pratense. Females lay their eggs in untidy piles of on average 205 eggs. The eggs are glued to each other with a strong adhesive substance, making it difficult to break apart the egg batch. This may protect the innermost eggs from predation. Prediapause larvae live in groups, spinning a conspicuous web that may cover the host plant entirely.

The larvae diapause in the third or fourth instar in the leaf litter around their host plants, probably in small groups (Wahlberg 1998). The postdiapause larvae feed singly on Melampyrum seedlings and bask singly on dark substrates. The larvae may diapause a second time if the conditions in the spring are not suitable for rapid growth (Wahlberg 1998).

The males use only perching tactic when searching for females to mate with (Wahlberg 1998). The males place a mating plug over the females' bursa copulatrix and the females probably mate only once.

\subsection{Euphydryas aurinia}

Egg. Nearly spherical with distinctly flattened base and flattened top; bright yellow when oviposited, changing to brown after 3 days and finally to purple just prior to hatching. Approximately 20 indistinct longitudinal ridges extending most of the distance from apex to base. Width $0.57 \mathrm{~mm}(\mathrm{n}=10)$, height $0.59 \mathrm{~mm}(\mathrm{n}=10)$.

First instar. Head black with colourless setae. Body transparent yellow with fine spotting, colour condensing into light brown after 4 days, but leaving circles of original body colour between papillae. Fore body coloured green by gut. Body with colourless setae arising from dark brown papillae, giving appearance of distinctly spotted body. True legs almost black, prolegs concolorous with body. First thoracic segment with prothoracic shield and last abdominal segment with dark suranal plate. Larva about $3 \mathrm{~mm}$ in length.

Second instar. Head black with colourless setae. Body brown with gut still colouring fore body dark green. Body with clear middorsal and ventrolateral bands. Branching spines develop from papillae and simple setae of first instar; spine shafts black with colourless setae; terminal seta about two times longer than other setae; base of shafts with cream yellow ring. True legs black, prolegs concolorous with body. Larva about $5 \mathrm{~mm}$ long.

Third instar. Head capsule black with light brown setae. Body brownish black with bluish grey middorsal and ventrolateral bands. Prolegs and underside brown, true legs black. Spine shafts black with light brown setae; terminal setae of equal length with other setae. Larva about $8 \mathrm{~mm}$ in length.

Fourth instar. Body, spines, setae, head capsule and true legs black. Middorsal and lateral bands made up of grey spots; fairly weak. Spiracles black. Prolegs light brown. Larva about 10 $\mathrm{mm}$ long.

Fifth instar. Overall pattern as in previous instar, but with banding pattern stronger and prolegs brown. Larva about $16 \mathrm{~mm}$ in length.

Sixth instar. Overall pattern as in previous instar, but with prolegs yellowish brown. Larva about $25 \mathrm{~mm}$ long.

Pupa. Ground colour white with black markings, abdominal segments with 5 orange cones on dorsal side.

Ecology. The life history of E. aurinia is described in detail in Klemetti and Wahlberg (1997). The butterfly is monophagous in Finland, feeding only on Succisa pratensis (Dipsacaceae). The females lay their eggs in batches of on average 270 eggs, usually in two neat layers. The eggs are glued to each other with a strong adhesive substance, making it difficult to break apart the egg batch. Prediapause larvae live in groups, spinning a conspicuous web that may cover the host plant entirely.

The larvae diapause in the fourth instar in groups within a winter web. The winter web is usually spun underneath a skeletonized leaf of the host plant and is difficult to see in the field. Postdiapause fourth instar larvae remain together in groups. Larvae bask together in sunny weather during spring and are able to raise their temperature well above ambient (Porter 1982). Basking promotes increased growth rates of the larvae in a group. Larvae may be able to escape parasitism by the braconid parasitoid Cotesia bignellii (Marshall), which are unable to take advantage of so- 
lar warmth and thus develop slower than their hosts (Porter 1982, Komonen 1997). Fifth instar larvae feed together in small groups, while sixth instar larvae are solitary. Larvae pupate singly within dense vegetation.

Adult males use both perching and patrolling tactics when searching for females to mate with (Klemetti \& Wahlberg 1997). The male places a mating plug over the female's genital opening and the females usually mate once (Porter 1981).

\section{Discussion}

All the species I have studied lay their eggs in batches. The eggs of the Euphydryas species are very different from those of the Melitaea species. A colour change from bright yellow when freshly laid to brownish after some days is typical of the Euphydryas group (Scott 1986) and can be considered unique to the group among the melitaeines. Furthermore, E. maturna and E. aurinia egg batches were very difficult to break apart when compared to the Melitaea egg batches.

The colouration of prediapause larvae does not vary much between species, but once again the larvae of the Euphydryas species are easy to separate from the Melitaea species. The Euphydryas larvae have fine spotting over the entire body, the last abdominal segment has a well-defined suranal plate and the terminal setae on the spines are much longer than the other setae, all three features which are missing or reduced in the Melitaea species.

In Melitaea diamina and $M$. athalia the sixth instar larvae are almost indistinguishable, which presents an interesting systematic problem. Higgins (1941) classified $M$. diamina as a close relative of $M$. cinxia on the basis of genital morphology. A recent molecular phylogeny shows that $M$. diamina is more closely related to $M$. athalia (Wahlberg \& Zimmermann, in press), suggesting that genital morphology is a plesiomorphic character, while larval colouration is a derived character in these three species.

There appears to be a relationship between the average size of the egg batches and the larval behaviour. The three species with large egg batches (M. cinxia, E. maturna and E. aurinia) are highly gregarious and spin dense webs over their host plants before diapause. Melitaea cinxia and $E$. aurinia are also gregarious after diapause. Small larvae may benefit from living in large groups if this reduces the cost of spinning a web per larva. This is an interesting hypothesis which deserves further investigation. Two studies on species in a closely related genus Chlosyne have shown that the larvae in the larger groups tend to grow faster than the larvae in the smaller groups (Clark \& Faeth 1997, Denno \& Benrey 1997). The two studies suggested different mechanisms for the observation. Clark and Faeth were of the opinion that the larger groups of recently hatched larvae were better able to overcome the physical toughness of the host plant's leaves. Denno and Benrey, however, were of the opinion that the larger groups of larvae were better able to overwhelm the defence of the host plant. Neither study investigated whether the faster growth in the larger groups is related to the web spinning ability.

All species diapause as half-grown larvae. The instar in which the diapause is initiated is usually the fourth, but this is not strict in some species. Melitaea cinxia may continue feeding in the fourth instar and diapause in the fifth if conditions are favourable (W. Fortelius, pers. comm.). The colour of the feeding fourth instar is unique. Euphydryas maturna is much more plastic in initiating diapause. I have recorded the third, fourth and fifth instars diapausing. The larvae may diapause twice, with the third and fourth instars diapausing the first time and the fifth instar larva diapausing the second time if necessary (Wahlberg 1998). There do not appear to be morphologically distinct instars that always diapause a second time.

Even though the general body plan of melitaeine larvae in Finland is very similar (as shown in Fig. 1), the colouration of the postdiapause larvae varies widely. Melitaeine larvae are generally thought to be unpalatable to vertebrate predators (Bowers 1983), and bright, aposematic colours may serve to warn predators. Another factor influencing the colouration of the larvae is the need for warmth in spring. Two species have predominantly black postdiapause larvae, $M$. cinxia and E. aurinia. Both species remain gregarious in spring and the larvae bask in groups, when the dark colour helps increasing the efficiency of gathering heat from the sun. The other three species are more or less solitary during spring and are also more colourful. These two characters appear 
to be correlated, but at this point I am unable to say whether there is a causal relationship between larval behaviour and aposematical colouration. A more detailed study with more species and a phylogenetic hypothesis is required (Harvey \& Pagel 1991).

All the studied species are highly specialized with regard to their host plants. In Finland $E$. aurinia and $M$. diamina are monophagous and the other species oligophagous. All the host plants are united by the presence of secondary compounds called iridoids (Jensen et al. 1975). Bowers (1983) found that North American Euphydryas species are able to sequester iridoids (which are bitter tasting compounds) and use them in their own defence against predators. The same is true for at least $M$. cinxia (M. Camara, pers. comm.).

Acknowledgements. I thank Marko Nieminen, Tomas Roslin and two anonymous referees for comments on the manuscript. I am grateful to Hanna Wahlberg for drawing Fig. 1. All appropriate permits for studying endangered species were procured prior to the onset of research from Pirkanmaan ympäristökeskus and Kymenlaakson ympäristökeskus.

\section{References}

Bowers, M. D. 1983: The role of iridoid glycosides in hostplant specificity of checkerspot butterflies. - J. Chem. Ecol. 9: 475-493.

Clark, B. R. \& Faeth, S. H. 1997: The consequences of larval aggregation in the butterfly Chlosyne lacinia. - Ecol. Ent. 22: 408-415.

Denno, R. F. \& Benrey, B. 1997: Aggregation facilitates larval growth in the neotropical nymphalid butterfly Chlosyne janais. - Ecol. Ent. 22: 133-141.

Ehrlich, P. R., White, R. R., Singer, M. C., McKechnie, S. W. \& Gilbert, L. E. 1975: Checkerspot butterflies: a historical perspective. - Science 188: 221-228

Hanski, I. \& Kuussaari, M. 1995: Butterfly metapopulation dynamics. - In: Cappuccino, N. \& Price, P.W. (eds.), Population Dynamics: New Approaches and Synthesis: 149-171. Academic Press, London. 429 pp.

Hanski, I., Kuussaari, M. \& Nieminen, M. 1994: Metapopulation structure and migration in the butterfly Melitaea cinxia. - Ecology 75: 747-762.

Hanski, I., Pakkala, T., Kuussaari, M. \& Lei, G. 1995: Metapopulation persistence of an endangered butterfly in a fragmented landscape. - Oikos 72: 21-28.

Harvey, P. H. \& Pagel, M. D. 1991: The comparative method in evolutionary biology. - Oxford University Press, Oxford. 239 pp.

Higgins, L. G. 1941: An illustrated catalogue of the Palearctic Melitaea (Lepidoptera: Rhopalocera). - Trans. R.
Ent. Soc. Lond. 91: 175-365.

Higgins, L. G. 1978: A revision of the genus Euphydryas Scudder (Lepidoptera: Nymphalidae). - Ent. Gaz. 29: 109-115.

Higgins, L. G. 1981: A revision of Phyciodes Hübner and related genera, with a review of the classification of the Melitaeinae (Lepidoptera: Nymphalidae). - Bull. Brit. Mus. Nat. Hist. 43: 77-243.

Jensen, S. R., Nielsen, B. J. \& Dahlgren, R. 1975: Iridoid compounds, their occurrence and systematic importance in the angiosperms. - Bot. Not. $128: 148-180$.

Karsholt, O. \& Razowski, J. 1996: The Lepidoptera of Europe: a distributional checklist. - Apollo Books, Stenstrup, Denmark.

Klemetti, T. \& Wahlberg, N. 1997: Punakeltaverkkoperhosen (Euphydryas aurinia) ekologia ja populaatiorakenne Suomessa. - Baptria 22: 87-93.

Komonen, A. 1997: Kirjoverkkoperhosen (Euphydryas maturna) ja punakeltaverkkoperhosen (Euphydryas aurinia) loiskiltojen rakenne Suomessa. - Baptria 22: 105-109.

Kuussaari, M. 1998: Biology of the Glanville fritillary butterfly (Melitaea cinxia). - Ph.D. thesis, University of Helsinki. 149 pp.

Kuussaari, M., Nieminen, M., Pöyry, J. \& Hanski, I. 1995: 'Iäpläverkkoperhosen (Melitaea cinxia) elinkierto ja esiintyminen Suomessa. - Baptria 20: 167-180.

Lei, G.-C., Vikberg, V., Nieminen, M. \& Kuussaari, M. 1997 : The parasitoid complex attacking Finnish populations of the Glanville fritillary Melitaea cinxia (Lepidoptera: Nymphalidae), an endangered butterfly. - J. Nat. Hist. 31: 635-648.

Porter, K. 1981: The population dynamics of small colonies of the butterfly Euphydryas aurinia. - D. Phil. thesis, University of Oxford. 285 pp.

Porter, K. 1982: Basking behaviour in larvae of the butterfly Euphydryas aurinia. - Oikos 38: 308-312.

Scott, J. A. 1986: The butterflies of North America. - Stanford University Press, Stanford. 583 pp.

Selonen, V. 1997: Kirjoverkkoperhosen (Euphydryas maturna) ja ratamoverkkoperhosen (Mellicta athalia) populaatiorakenne ja habitaatinvalinta. - Baptria 22: 137-144.

Wahlberg, N. 1995: Täpläverkkoperhosen (Melitaea cinxia) lisääntymisbiologia. - Baptria 20: 181-188.

Wahlberg, N. 1997a: The life history and ecology of Melitaea diamina (Nymphalidae) in Finland. - Nota lepid. 20: 70-81.

Wahlberg, N. 1997b: Ratamoverkkoperhosen (Mellicta athalia) elinkierto Etelä-Suomessa. - Baptria 22: 149-153.

Wahlberg, N. 1998: The life history and ecology of Euphydryas maturna (Nymphalidae: Melitaeini) in Finland. - Nota lepid. 21: 154-169.

Wahlberg, N. 1999: Kirjoverkkoperhosen (Euphydryas maturna) elinympäristöstä Suomessa - Baptria 24: 173-177.

Wahlberg, N. \& Zimmermann, M. 2000: Pattern of phylogenetic relationships among members of the tribe $\mathrm{Mel}$ itaeini (Lepidoptera: Nymphalidae) inferred from mtDNA sequences. - Cladistics, in press. 